\title{
Gallbladder metastasis of renal clear cell carcinoma 15 years after primary cancer excision: a case report
}

\author{
Yasufumi Saito ${ }^{1 *}$, Hiroshi Okuda², Makoto Yoshida', Seiji Okimasa ${ }^{3}$, Toshikatsu Fukuda', Masatsugu Yano1, \\ Makoto Ochi', Yuzo Okamoto ${ }^{1}$, Hirofumi Nakayama ${ }^{5}$, Eiji Ono ${ }^{1}$ and Hideki Ohdan ${ }^{6}$
}

\begin{abstract}
Background: Renal cell carcinoma is well-known for its propensity to metastasize to unusual sites. However, metastasis to the gallbladder has been rarely reported in the literature.

Case presentation: A 75-year-old Japanese (Asian) woman presented for further evaluation of a gallbladder polyp, 15 years after right radical nephrectomy for renal cell carcinoma. Computed tomography revealed a $12 \mathrm{~mm}$ enhancing pedunculated tumor in the gallbladder fundus. Open simple cholecystectomy was performed and the tumor was histologically confirmed as a metastasis of renal cell carcinoma to the gallbladder. Our patient is alive and has been disease-free for 3 years after cholecystectomy.

Conclusions: Although metastasis of renal cell carcinoma is a rare differential diagnosis of gallbladder tumors, simple cholecystectomy is likely to offer a chance of long-term survival for patients with gallbladder metastases of renal cell carcinoma.
\end{abstract}

Keywords: Renal cell carcinoma, Metastasis, Gallbladder

\section{Background}

Metastasis to the gallbladder is rare and in most cases is found incidentally on autopsy $[1,2]$. The rarity and clinical similarity of metastasis to the gallbladder to benign or other malignant gallbladder diseases make a correct diagnosis difficult in clinical practice.

Cancers of the kidney account for $4 \%$ of all newly diagnosed malignancies in men and 3\% in women, and in most cases they are renal cell carcinomas (RCCs) [3]. Approximately one-third of patients with RCC already have metastases at the time of diagnosis, frequently to vascular-rich organs such as the lung, bone, and liver. Patients with distant metastases from RCC have a poor prognosis with a prospect of surviving for 5 years of $<$ $10 \%$ [4]. However, curative resection of metastases in selected patients may improve long-term survival [5]. In patients with a solitary metastasis, a $35-50 \%$ prospect of

\footnotetext{
* Correspondence: ngywc515@ybb.ne.jp

${ }^{1}$ Department of Surgery, Medical Corporation JR Hiroshima Hospital, 3-1-36

Futabanosato, Higashi-ku, Hiroshima 732-0057, Japan

Full list of author information is available at the end of the article
}

surviving for 5 years after complete metastasectomy has been reported $[4,6]$.

We report a rare case of a patient with gallbladder metastasis from RCC diagnosed 15 years after primary cancer excision, and review the previously reported 38 cases. We discuss the condition's presentation, surgical treatment, and survival outcomes. We also indicated the characteristics of preoperative image findings of gallbladder metastasis of RCC, which are considered to be helpful for the preoperative differential diagnosis of gallbladder tumors. It was thought to be clinically important that resection could allow long-term survival for patients with metachronous and localized RCC recurrences.

\section{Case presentation}

A 75-year-old Japanese (Asian) woman underwent a right nephrectomy for RCC approximately 15 years ago. Our patient did not present symptoms at admission, and her past medical, social, family, and environmental history was not appreciable. Her occupation was home manager, and she was on no medication prior to 


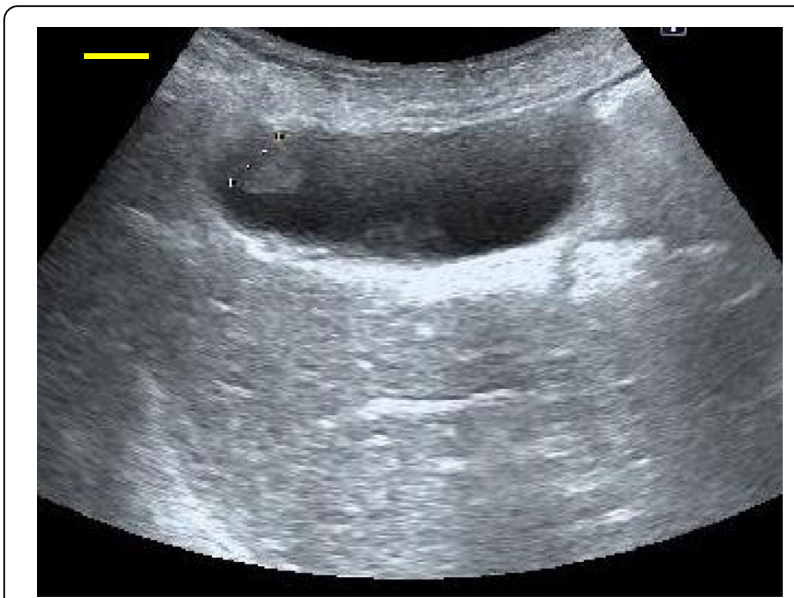

Fig. 1 Ultrasonography shows an iso- to hyperechoic polyp at the fundus of the gallbladder (yellow bar indicates $10 \mathrm{~mm}$ )

diagnosis. She did not smoke and consume alcohol, and her temperature was $36.3{ }^{\circ} \mathrm{C}$, her blood pressure was 122/82 $\mathrm{mmHg}$, and her pulse was 68 per minute. Laboratory findings at admission are shown below. Her white blood cell count was $3800 \times 10^{3 /} \mu \mathrm{L}$, red blood cell count $414 \times 10^{4} / \mu \mathrm{L}$, hemoglobin $13.0 \mathrm{~g} / \mathrm{dL}$, hematocrit $39.1 \%$, platelets $19.6 \times 104 / \mu \mathrm{L}$, total bilirubin $0.7 \mathrm{mg} / \mathrm{dL}$, direct bilirubin $0.2 \mathrm{mg} / \mathrm{dL}$, aspartate transaminase $23 \mathrm{IU} / \mathrm{L}$, alanine transaminase $9 \mathrm{IU} / \mathrm{L}$, total protein $7.3 \mathrm{~g} / \mathrm{dL}$, albumin $4.5 \mathrm{~g} /$ $\mathrm{dL}$, lactate dehydrogenase $188 \mathrm{IU} / \mathrm{L}, \gamma$-glutamyltransferase $11 \mathrm{IU} / \mathrm{L}$, alkaline phosphatase $201 \mathrm{IU} / \mathrm{L}$, amylase $129 \mathrm{IU} / \mathrm{L}$, blood urea nitrogen $13.6 \mathrm{mg} / \mathrm{dL}$, creatinine $0.64 \mathrm{mg} / \mathrm{dL}$, sodium $137 \mathrm{mEq} / \mathrm{L}$, potassium $3.9 \mathrm{mEq} / \mathrm{L}$, chlorine $\mathrm{mEq} / \mathrm{L}$, C-reactive protein $0.03 \mathrm{mg} / \mathrm{dL}$, carcinoembryonic antigen $1.5 \mathrm{ng} / \mathrm{mL}$, carbohydrate antigen $19-94 \mathrm{U} / \mathrm{mL}$, urinalysis $\mathrm{pH}$ 7.0, no uric protein, no urinary sugar, no ketone body, no uric blood, no bilirubin, and no white blood cell. No microbial examination was performed.

The tumor was $9.1 \times 7.8 \mathrm{~cm}$ in diameter and confined to the capsule of the kidney. Pulmonary lobectomy was performed for left lung metastasis 11 years after the primary resection and an additional lung partial resection was performed for the metachronous left lung metastasis 14 years after the primary resection.

Examinations including whole body computed tomography (CT) before each surgery demonstrated no evidence of distant metastasis. A surveillance follow-up CT scan revealed a gallbladder lesion. No symptoms suggested cholecystitis, and the only biochemical abnormality was a slight elevation in levels of aspartate transaminase and alanine transaminase. Ultrasonography (US) showed a mass at the gallbladder fundus. Its surface was smooth, and the inner echo was slightly high and homogenous (Fig. 1).

A contrast-enhanced CT scan showed a 12-mm polypoid mass with high attenuation, enlarged from $4 \mathrm{~mm} 2$ years ago (Fig. 2a, b). It had significantly high intensity in the arterial phase. On the coronal reconstruction image, attenuation was inhomogeneous in the mass and relatively higher on the wall side (Fig. 2c, d). There was
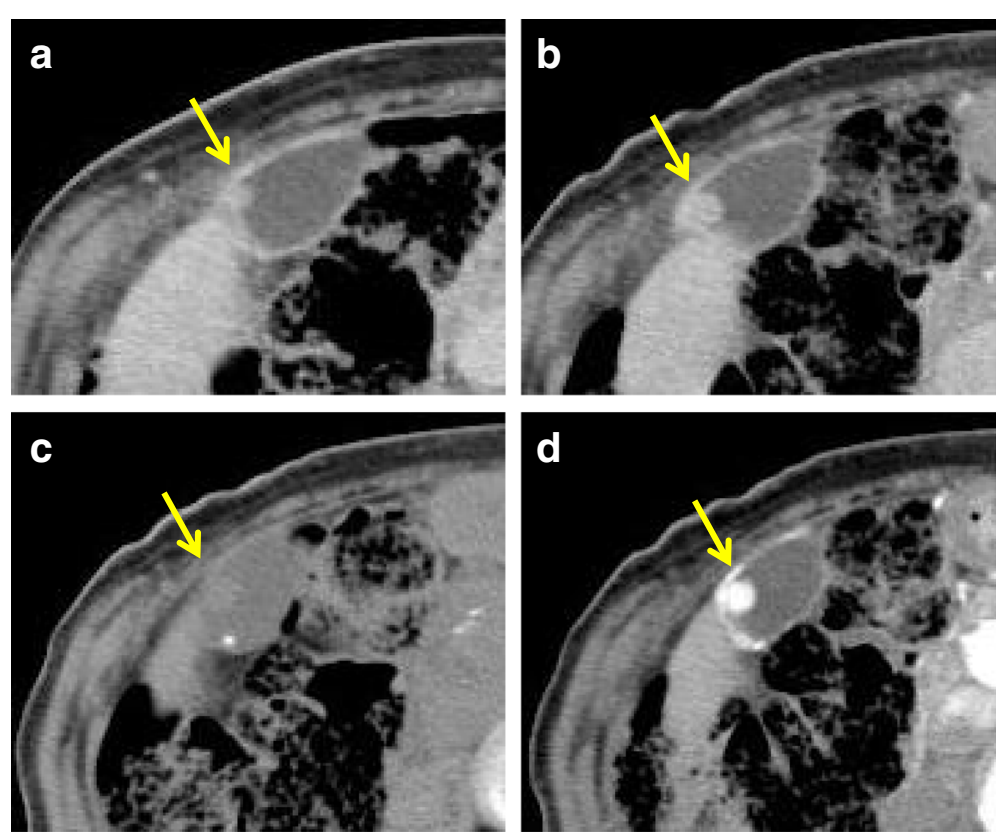

Fig. 2 A computed tomography scan shows tumor growth from $4 \mathrm{~mm}$ to $12 \mathrm{~mm}$ over a span of 2 years (a 2 years prior, $\mathbf{b}$ present). A contrast-enhanced computed tomography scan shows high intensity of the tumor during the arterial phase (d yellow arrow) in comparison with plain computed tomography (c yellow arrow) 
no significant accumulation of contrast agent in any organ other than the gallbladder.

Based on these image findings and the patient's medical history, we initially thought the gallbladder mass was a malignant tumor such as a gallbladder carcinoma. The possibility that the tumor was metastatic cancer remained, and we therefore performed open approach cholecystectomy to confirm the diagnosis and perform adequate treatment.

The isolated specimen showed a pedunculated tumor in the fundus of the gallbladder, and the surface of the tumor appeared black as a result of bleeding (Fig. 3a). Microscopically, we observed prominent vascular proliferation in the stalk and basal part of the tumor (Fig. 3b). The tumor was hypercellular and composed of clear cells arranged in funicular or alveolar growth with vascular interstitial tissue (Fig. 3c). The surface of the tumor was covered by epithelium, and extensive hemorrhage was observed under the surface (Fig. 3b). These histopathologic characteristics coincided with those of the renal tumor resected 15 years earlier (Fig. 3d, e).
We performed immunohistochemical staining for vimentin and cytokeratin 7 (CK7). The tumor stained strongly for vimentin, but staining for CK7 was almost negative (Fig. 4), although for CK7, we observed a partially nonspecific immune reaction due to use of an automated immunostainer. These pathological features were similar to those of the renal primary tumor. Therefore, we diagnosed the gallbladder tumor as a metastasis from renal cell carcinoma. Our patient's postoperative course was uneventful and she was discharged at postoperative day 5 . She is alive and recurrence free 3 years after cholecystectomy.

\section{Discussion}

This report showed a rare case of a patient who underwent open simple cholecystectomy and presented gallbladder metastasis from RCC. Even when compared with previous literature, the period from primary resection to gallbladder metastasis was relatively long. This observation shows that patients with metachronous and localized recurrences of RCC could be expected to achieve long-term survival following resection.
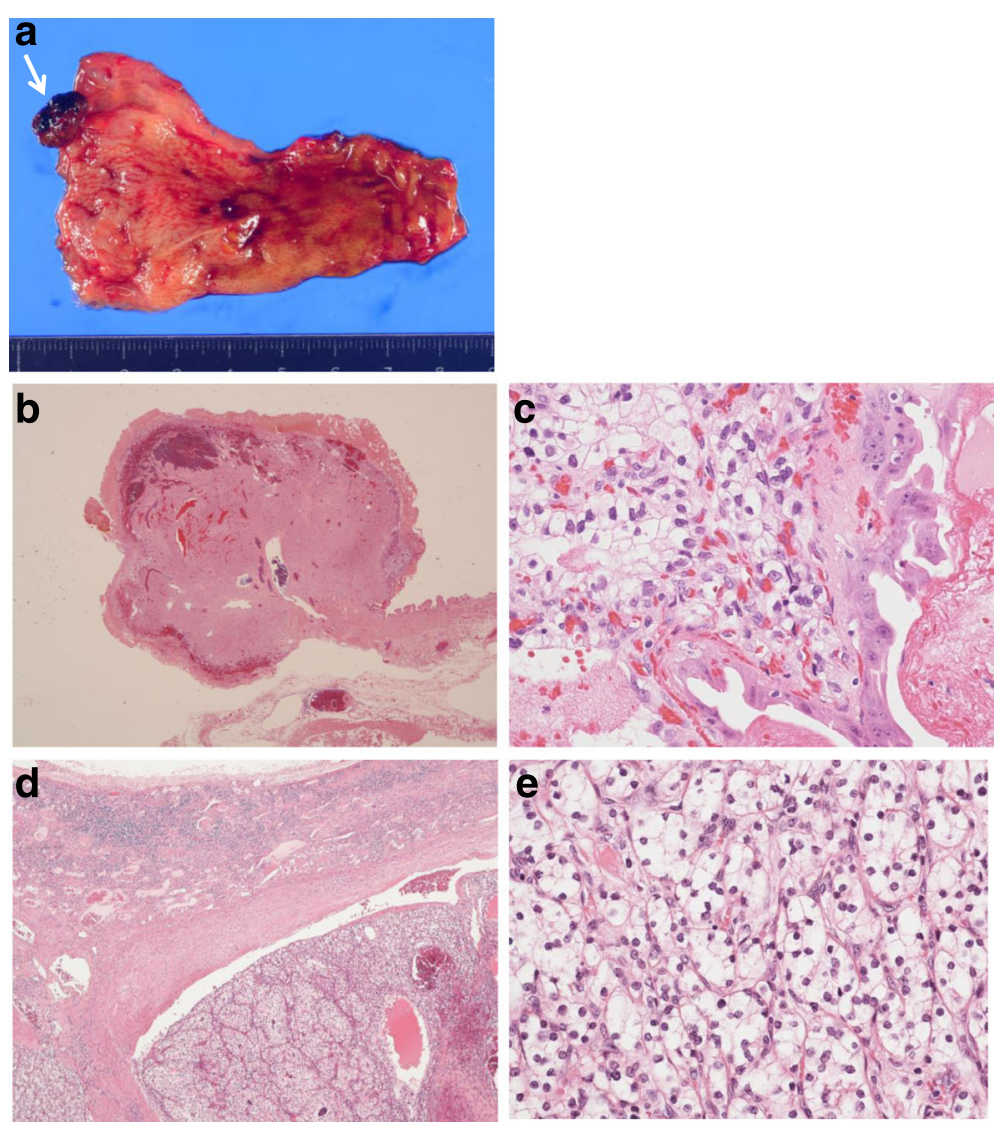

Fig. 3 The surgical specimen shows a black pedunculated tumor in the fundus of the gallbladder (a white arrow). Pathological examination of hematoxylin and eosin staining shows tumor cells with clear cellular cytoplasm growth $(\mathbf{b} \times 20, \mathbf{c} \times 200)$, and it is similar to the features of the renal primary tumor $(\mathbf{d} \times 20$, e $\times 200)$ 

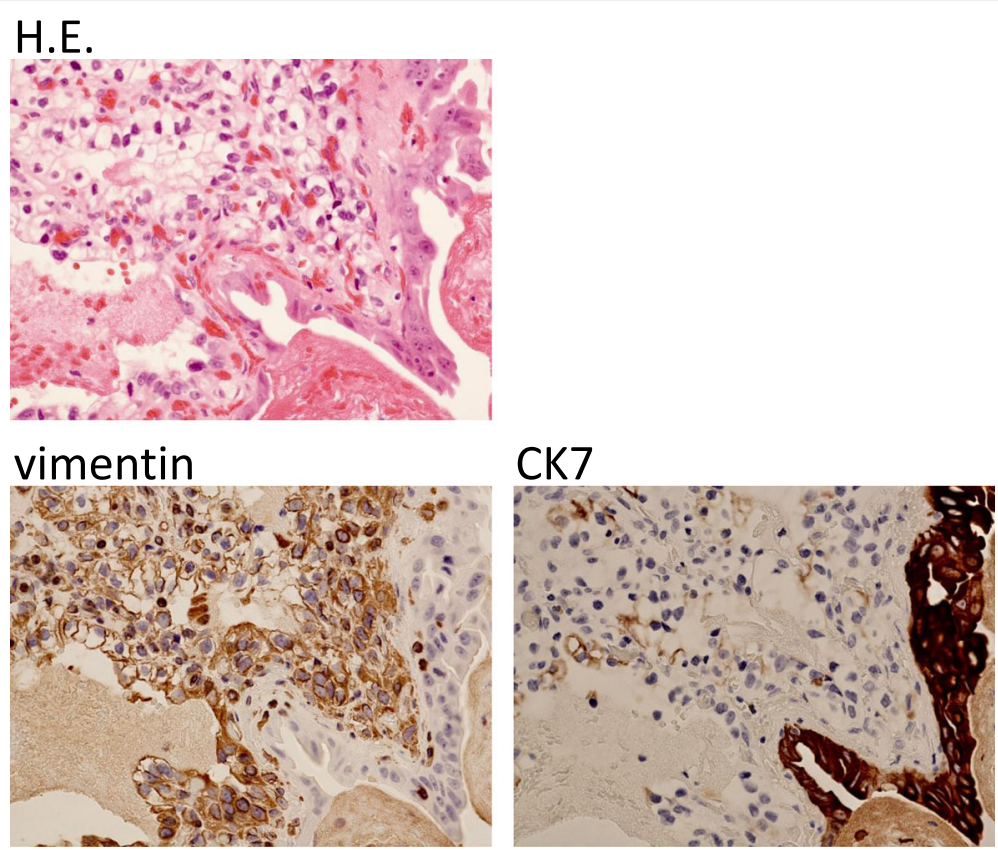

Fig. 4 Immunohistochemistry staining for vimentin shows that the tumor cells stain strongly but the gallbladder epithelium is negative. CK7 immunohistochemical staining also shows that the tumor cells barely stain, but the gallbladder epithelium stains strongly

Distant metastases of RCC discovered during autopsy are found mostly in the lungs, liver, bones, and contralateral kidney. Metastasis to the gallbladder is very rare and is found in only $0.4-0.58 \%$ of autopsy cases due to RCC [2].

Malignant melanomas are the most common cause of metastatic tumors of the gallbladder in Western countries, and metastases from lung, renal, pancreatic, and colorectal cancers to the gallbladder have also been reported [2, 7]. To date, only 38 cases of RCC metastasizing to the gallbladder have been reported. Furthermore, there have only been seven cases, including this one, in which the metastasis was diagnosed 10 or more years after surgical resection of the RCC [3, 8-13]. In all these cases, the histological type was clear cell carcinoma.

On previous report, the processes of metastasis to the gallbladder was grouped into two types, direct invasion of the tumor and invasion of the tumor into the capillaries, stating that the latter process is comparatively rare [2]. Gallbladder metastases occurred simultaneously in half of the cases and recurred metachronously in the other half. Another characteristic of these cases is the wide time range: 12 months to 27 years between the resection of the primary tumor and the reappearance of the tumor cells.

Dynamic contrast-enhanced CT is useful in the differential diagnosis of a metastatic gallbladder tumor from RCC and a primary gallbladder carcinoma, because the former is hypervascular $[14,15]$. In the case we describe, contrast-enhanced CT showed the mass had high density on an arterial enhanced phase image. Another characteristic of these cases is the appearance of an echo-bright area on the surface of the tumor, indicating a submucosal tumor on US [16].

Only two reports have described the use of positron emission tomography (PET)/CT scans to differentiate gallbladder metastasis from RCC $[2,16]$. Kawahara and colleagues documented a tumor mass on the gallbladder wall on PET/CT images without high accumulation of fluorodeoxyglucose (FDG) [2]. The role of PET/CT in gallbladder metastasis from RCC remains undefined.

Although RCC has some typical imaging characteristics, it remains extremely difficult to distinguish cases of primary and metastatic gallbladder carcinoma. In cases of RCC in which a gallbladder mass is observed simultaneously or metachronously, the possibility of gallbladder metastasis should be taken into account, although it is difficult to arrive at a preoperative diagnosis of gallbladder metastasis.

In the present patient, the gallbladder tumor was polypoid and over $10 \mathrm{~mm}$ in size. Furthermore, contrastenhanced CT showed a high density on an arterial phase imaging. We thought it might be a gallbladder polyp or a malignant lesion, so we performed simple cholecystectomy for diagnosis and treatment since no suspicious findings of tumor invasion into the muscle layer of the gallbladder on preoperative imaging or intraoperative findings were noted.

Kavolius et al. have reported single organ metastasis and recurrence-free survival as prognostic factors after 
Table 1 Previously reported cases of metastatic renal cell carcinoma of the gallbladder. Permission was granted by Ishizawa T., Okuda J., Kawanishi T. et al. @ A Asian Surgical Association and published by Elsevier B.V. 2006 to reuse this table

\begin{tabular}{|c|c|c|c|c|c|c|c|c|c|c|}
\hline Author & Age/Sex & $\begin{array}{l}\text { Mode of } \\
\text { metastasis }\end{array}$ & $\begin{array}{l}\text { Syn or } \\
\text { Meta }\end{array}$ & $\begin{array}{l}\text { Interval from } \\
\text { primary cancer }\end{array}$ & $\begin{array}{l}\text { Other site } \\
\text { of meta }\end{array}$ & $\begin{array}{l}\text { Op } \\
\text { procedure }\end{array}$ & $\begin{array}{l}\text { Macroscopic } \\
\text { findings }\end{array}$ & Size $(\mathrm{cm})$ & Outcome & $\begin{array}{l}\text { Year of } \\
\text { source }\end{array}$ \\
\hline $\begin{array}{l}\text { Saito (present } \\
\text { case) }\end{array}$ & $75 / F$ & Solitary & Meta & $15 y$ & Lung & SC & Pedunculated & $1.2 \times 0.9$ & $2 y$ alive & 2018 \\
\hline Botting [18] & $66 / M$ & Solitary & Meta & 1 y $7 \mathrm{~m}$ & $(-)$ & SC & Polypoid & $4.2 \times 2$ & ND & 1963 \\
\hline Terashima [19] & $61 / M$ & Multiple & Syn & $(-)$ & Bone & EC & Mass & $2 \times 2$ & $2 \mathrm{~m}$ death & 1990 \\
\hline Satoh et al. [7] & $71 / \mathrm{M}$ & Solitary & Syn & $(-)$ & Pancreas & $\mathrm{EC}$ & $\begin{array}{l}\text { Mushroom- } \\
\text { shaped }\end{array}$ & $4 \times 2.5$ & 1 y $7 \mathrm{~m}$ alive & 1991 \\
\hline Fullarton [20] & $43 / F$ & Multiple & Syn & $(-)$ & $\begin{array}{l}\text { Pancreas, } \\
\text { kidney }\end{array}$ & SC & Mass & 3 & $\begin{array}{l}5 \mathrm{~m} \text { died from } \\
\text { cancer }\end{array}$ & 1991 \\
\hline Golbey [21] & $84 / \mathrm{M}$ & Solitary & Meta & $13 y$ & $(-)$ & SC & Pedunculated & 3.5 & ND & 1991 \\
\hline Nagler [22] & $82 / M$ & Solitary & Meta & $5 y$ & $(-)$ & EC & Polypoid & $3 \times 3$ & ND & 1994 \\
\hline Pagano [23] & $62 / \mathrm{M}$ & Solitary & Syn & $(-)$ & Lung & SC & Round mass & 3.5 & disease free & 1995 \\
\hline King [24] & $64 / M$ & Solitary & Syn & $(-)$ & $(-)$ & SC & Polypod & unclear & $\begin{array}{l}2 \text { y } 2 \mathrm{~m} \text { disease } \\
\text { free }\end{array}$ & 1995 \\
\hline Fujii [25] & $69 / M$ & Multiple & Syn & $(-)$ & Adrenal gland & $\mathrm{EC}$ & Polypoid & $2.8 \times 2.5$ & $3 \mathrm{~m}$ disease free & 1995 \\
\hline Coskun [26] & $52 / \mathrm{M}$ & Multiple & Syn & $(-)$ & bone & SC & Polypoid & $3.5 \times 2.5$ & ND & 1995 \\
\hline Lombardo [27] & $77 / M$ & Solitary & Meta & $5 y$ & $(-)$ & $\mathrm{EC}$ & Polypoid & $3 \times 3$ & ND & 1996 \\
\hline Kamimoto [28] & $53 / \mathrm{M}$ & Multiple & Meta & $4 y$ & $(-)$ & LC & Polypoid & 1.5 & $6 \mathrm{~m}$ alive & 1996 \\
\hline Sparwasser [29] & $46 / \mathrm{M}$ & Solitary & Meta & 3 y $8 \mathrm{~m}$ & $\begin{array}{l}\text { (-) Lung } \\
\text { resected }\end{array}$ & SC & Polypoid & $2.7 \times 2.1$ & $\begin{array}{l}4 \text { y } 4 \mathrm{~m} \text { died from } \\
\text { cancer }\end{array}$ & 1997 \\
\hline Furukawa et al. [14] & $41 / \mathrm{M}$ & Multiple & Syn & $(-)$ & $\begin{array}{l}\text { Lung, chest } \\
\text { wall }\end{array}$ & SC & Pedunculated & $1.9 \times 1.3$ & ND & 1997 \\
\hline Uchiyama [30] & $64 / \mathrm{M}$ & Multiple & Meta & $3 y$ & Kidney & SC & Pedunculated & $1.9 \times 1.1$ & $7 \mathrm{~m}$ alive & 1997 \\
\hline Celebi [31] & $73 / \mathrm{M}$ & Solitary & Syn & $(-)$ & Lung & $\mathrm{EC}$ & $\begin{array}{l}\text { Mushroom- } \\
\text { shaped }\end{array}$ & $2.8 \times 2$ & $\begin{array}{l}1 \mathrm{~m} \text { died from } \\
\text { other disease }\end{array}$ & 1998 \\
\hline Ueki [32] & $69 / F$ & Solitary & Syn & $(-)$ & $(-)$ & EC & Pedunculated & 1.6 & $7 \mathrm{~m}$ disease free & 2001 \\
\hline Gekiya [33] & $68 / M$ & Solitary & Meta & $15 y$ & $(-)$ & SC & Polypoid & ND & 1 y disease free & 2002 \\
\hline Aoki [34] & $63 / \mathrm{M}$ & Solitary & Meta & $27 y$ & $(-)$ & SC & Pedunculated & $7.5 \times 3$ & 6 y disease free & 2002 \\
\hline Aoki [34] & $80 / \mathrm{M}$ & Solitary & Meta & $8 y$ & Lung & SC & Pedunculated & $4.5 \times 2.5$ & 2 y disease free & 2002 \\
\hline Miyagi [35] & $53 / \mathrm{M}$ & Solitary & Meta & 10 y $6 \mathrm{~m}$ & $(-)$ & LC & Polypoid & $2.5 \times 1.5$ & ND & 2003 \\
\hline Limani [36] & $64 / M$ & Solitary & Meta & $1 y$ & $(-)$ & LC & Mass & ND & ND & 2003 \\
\hline Ishizawa et al. [15] & 73/M & Solitary & Meta & $5 y$ & $(-)$ & SC & Pedunculated & $3.5 \times 2$ & 2 y disease free & 2006 \\
\hline Hellenthal [37] & $39 / \mathrm{M}$ & Solitary & Syn & $(-)$ & $(-)$ & SC & Polypoid & ND & 2 y $6 \mathrm{~m}$ alive & 2007 \\
\hline Ricci [9] & $72 / F$ & Solitary & Meta & $16 y$ & Pancreas & LC & Mass & ND & ND & 2008 \\
\hline Nojima [38] & $61 / M$ & Solitary & Syn & $(-)$ & $(-)$ & SC & Polypoid & 1.5 & $10 \mathrm{~m}$ alive & 2008 \\
\hline Sand [39] & $48 / F$ & Solitary & Meta & $5 y$ & $\begin{array}{l}\text { Pancreas, } \\
\text { kidney }\end{array}$ & SC & ND & ND & $2 \mathrm{~m}$ alive & 2009 \\
\hline Patel et al. [1] & $64 / F$ & Solitary & Meta & $6 y$ & $(-)$ & LC & Polypoid & 3 & ND & 2009 \\
\hline Kawahara et al. [2] & $73 / F$ & Solitary & Syn & $(-)$ & Lung & SC & Polypoid & $1.0 \times 0.8$ & ND & 2010 \\
\hline Shoji et al. [8] & $50 / \mathrm{M}$ & Multiple & Meta & $3 y$ & Adrenal grand & SC & Polypoid & $1.1 \times 0.9$ & $8 \mathrm{~m}$ alive & 2010 \\
\hline Fang et al. [13] & $45 / \mathrm{M}$ & Solitary & Meta & $1 y$ & Lung & SC & Polypoid & $1.9 \times 1.0$ & 2 y 4 m death & 2010 \\
\hline Fang et al. [13] & $65 / F$ & Solitary & Meta & $1 y$ & Psoas muscle & SC & Polypoid & $2.5 \times 2.5$ & $7 \mathrm{~m}$ death & 2010 \\
\hline Fang et al. [13] & $54 / M$ & Solitary & Meta & $7 y$ & $(-)$ & SC & Polypoid & $1.5 \times 1.0$ & 2 y $3 \mathrm{~m}$ alive & 2010 \\
\hline Fang et al. [13] & $51 / \mathrm{M}$ & Solitary & Meta & $6 y$ & Kidney & SC & Polypoid & $1.7 \times 0.8$ & 3 y $1 \mathrm{~m}$ alive & 2010 \\
\hline Decoene et al. [10] & $47 / F$ & Solitary & Meta & $16 y$ & Bone, ovary & LC & Polypoid & 1.9 & ND & 2011 \\
\hline
\end{tabular}


Table 1 Previously reported cases of metastatic renal cell carcinoma of the gallbladder. Permission was granted by Ishizawa T., Okuda J., Kawanishi T. et al. @ Asian Surgical Association and published by Elsevier B.V. 2006 to reuse this table (Continued)

\begin{tabular}{|c|c|c|c|c|c|c|c|c|c|c|}
\hline Author & Age/Sex & $\begin{array}{l}\text { Mode of } \\
\text { metastasis }\end{array}$ & $\begin{array}{l}\text { Syn or } \\
\text { Meta }\end{array}$ & $\begin{array}{l}\text { Interval from } \\
\text { primary cancer }\end{array}$ & $\begin{array}{l}\text { Other site } \\
\text { of meta }\end{array}$ & $\begin{array}{l}\text { Op } \\
\text { procedure }\end{array}$ & $\begin{array}{l}\text { Macroscopic } \\
\text { findings }\end{array}$ & Size $(\mathrm{cm})$ & Outcome & $\begin{array}{l}\text { Year of } \\
\text { source }\end{array}$ \\
\hline $\begin{array}{l}\text { Jain and Chopra } \\
\text { [12] }\end{array}$ & $49 / F$ & Solitary & Meta & $6 y$ & $(-)$ & SC & Polypoid & $1.45 \times 1.0$ & ND & 2013 \\
\hline Ueda et al. [3] & $43 / \mathrm{M}$ & Solitary & Meta & $1 y$ & $(-)$ & EC & Pedunculated & 2.6 & ND & 2015 \\
\hline
\end{tabular}

Abbreviations: Syn synchronous metastasis, Meta metachronous metastasis, SC simple cholecystectomy, ND not determined, EC extended cholecystectomy, LC laparoscopic cholecystectomy

resection of metachronous metastatic lesions [5]. Chung et al. reported eight cases of patients with isolated gallbladder metastasis recurrence-free survival (observed median 1.1 years, range from 0.1 to 6 years) in a cohort study of 33 renal cell carcinoma cases [9], and they thought that isolated gallbladder single metastasis was an indication for surgery.

Although extended cholecystectomy is the standard operation when there is a strong suspicion of primary gallbladder cancer, it is important to excise metastatic lesions of RCC to the gallbladder. In Table 1 , nine cases of simple cholecystectomy, including laparoscopic surgery, for an isolated metastasis to the gallbladder resulted in cancer-free survival in all cases (including the present case). Therefore, if there is no obvious invasion of the gallbladder bed, a simple resection including laparoscopic surgery is expected to be curative.

For an adequate follow-up and informed decisions about adjuvant immunotherapy with interleukin-2 and interferon alpha after cholecystectomy, gallbladder metastasis of RCC should be differentiated from primary clear cell carcinoma of the gallbladder through histochemical examination. Immunohistochemically, primary clear cell carcinoma of the gallbladder is strongly positive for CK7 but negative for vimentin, and metastatic RCC of the gallbladder is positive for vimentin but negative for CK7 [17]. Based on the immunohistochemical findings, our final diagnosis was metastatic gallbladder tumor from RCC as opposed to primary clear cell carcinoma of the gallbladder.

The follow-up information on the previously reported cases is not sufficient to demonstrate the curability of cholecystectomy for a metastasis of RCC, since late recurrence is not uncommon with RCC. However, nine patients were reported to be cancer free with the longest follow-up interval of 6 years after cholecystectomy, and eight of these had a solitary metastasis. These reports suggest a favorable prognosis after cholecystectomy, particularly in patients with a solitary metastasis. Even for multiple metastases of RCC, cholecystectomy may be advocated, because the survival rates after curative resection of second and third metastases have not been found to be different from those after a first metastectomy [5].

\section{Conclusions}

In conclusion, we describe a rare case of gallbladder metastasis from RCC diagnosed 15 years after primary cancer resection. In patients with a history of RCC, observation of a vascular-rich polypoid lesion of the gallbladder should raise the possibility of metastasis. Cholecystectomy may result in favorable long-term survival of patients with RCC metastases to the gallbladder.

\section{Abbreviations \\ CK7: Cytokeratin 7; CT: Computed tomography; FDG: Fluorodeoxyglucose; PET: Positron emission tomography; RCC: Renal cell carcinoma; US: Ultrasonography}

\section{Acknowledgements}

Not applicable.

Funding

This case report had no source of financial or material support.

Availability of data and materials

Ishizawa et al. [15] gave their consent to reuse the Table of their publication in Table 1 of this publication.

\section{Declarations}

The authors guarantee that the work described in this study has not been published previously.

\section{Authors' contributions}

YS wrote this manuscript. $\mathrm{HO}, \mathrm{MY}, \mathrm{SO}, \mathrm{TF}, \mathrm{MY}, \mathrm{MO}, \mathrm{YO}, \mathrm{HN}, \mathrm{EO}$, and $\mathrm{HO}$ helped to draft the manuscript and revised it critically. All authors have read and approved the final manuscript.

\section{Authors' information}

YS, MY, TF, MY, and YO are Staff Surgeons of the Department of Surgery, Medical Corporation JR Hiroshima Hospital. HO is a Staff Surgeon of the Department of Surgery, Onomichi General Hospital. SO is a Staff Doctor in Palliative Care, Medical Corporation JR Hiroshima Hospital. MO is a Staff Member in Dialysis Surgery, Medical Corporation JR Hiroshima Hospital. HN is a Pathologist in the Department of Pathology and Laboratory Medicine, Medical Corporation JR Hiroshima Hospital. EO is the Hospital Director, Medical Corporation JR Hiroshima Hospital, and HO is a Professor of the Department of Gastroenterological and Transplant Surgery, Applied Life Sciences, Institute of Biomedical \& Health Sciences, Hiroshima University.

\section{Ethics approval and consent to participate}

This case report has been approved by the research ethics committee and written informed consent was obtained from the patient for participation of this case report.

\section{Consent for publication}

Written informed consent was obtained from the patient for publication of this case report and any accompanying images. A copy of the written consent is available for review by the Editor-in-Chief of this journal. 


\section{Competing interests}

The authors declare that they have no competing interests.

\section{Publisher's Note}

Springer Nature remains neutral with regard to jurisdictional claims in published maps and institutional affiliations.

\section{Author details}

${ }^{1}$ Department of Surgery, Medical Corporation JR Hiroshima Hospital, 3-1-36 Futabanosato, Higashi-ku, Hiroshima 732-0057, Japan. ${ }^{2}$ Department of Surgery, Onomichi General Hospital, Onomichi, Hiroshima, Japan. ${ }^{3}$ Department of Palliative Care, Medical Corporation JR Hiroshima Hospital, Hiroshima, Japan. ${ }^{4}$ Department of Dialysis Surgery, Medical Corporation JR Hiroshima Hospital, Hiroshima, Japan. ${ }^{5}$ Department of Pathology and Laboratory Medicine, Medical Corporation JR Hiroshima Hospital, Hiroshima, Japan. ${ }^{6}$ Department of Gastroenterological and Transplant Surgery, Applied Life Sciences, Institute of Biomedical \& Health Sciences, Hiroshima University, Hiroshima, Japan.

\section{Received: 11 July 2017 Accepted: 10 January 2018}

Published online: 31 May 2018

\section{References}

1. Patel S, Zebian B, Gurjar S, et al. An unusual gall-bladder polyp-site of metastatic renal cell carcinoma: a case report. Cases J. 2009;2:172.

2. Kawahara $\mathrm{T}$, Ohshiro $\mathrm{H}$, Sekiguchi $\mathrm{Z}$, et al. Gallbladder metastasis from renal cell carcinoma. Case Rep Oncol. 2010;3:30-4.

3. Ueda I, Aoki T, Oki H, et al. Gallbladder metastasis from renal cell carcinoma: a case report with review of the literature. Magn Reson Med Sci. 2015;14:133-8.

4. Vogelzang NJ, Stadler WM. Kidney cancer. Lancet. 1998;352:1691-6.

5. Kavolius JP, Mastorakos DP, Pavlovich C, Russo P, Burt ME, Brady MS. Resection of metastatic renal cell carcinoma. J Clin Oncol. 1998;16:2261-6.

6. Klugo RC, Detmers M, Stiles RE, Talley RW, Cerny JC. Aggressive versus conservative management of stage IV renal cell carcinoma. J Urol. 1977:118:244-6.

7. Satoh H, lyama A, Hidaka K, Nakashiro H, Harada S, Hisatsugu T. Metastatic carcinoma of the gallbladder from renal cancer presenting as intraluminal polypoid mass. Dig Dis Sci. 1991;36:520-3.

8. Shoji S, Mukai M, Yazawa N, et al. Metastasis to gallbladder and adrenal gland of renal cell carcinoma. Oncol Lett. 2010;1:507-9.

9. Chung PH, Srinivasan R, Linehan WM, Pinto PA, Bratslavsky G. Renal cell carcinoma with metastases to the gallbladder: four cases from the National Cancer Institute (NCI) and review of the literature. Urol Oncol. 2012;30:476-81.

10. Decoene J, Ameye F, Lerut E, Oyen R, Van Poppel H, Joniau S. Renal cell carcinoma with synchronous metastasis to the calcaneus and metachronous metastases to the ovary and gallbladder. Case Rep Med. 2011;2011:671645

11. Gajendra S, Sachdev R, Mohapatra I, Goel R, Goel S. Metastatic renal cell carcinoma: an unusual cause of bleeding pancreatic mass. J Clin Diagn Res. 2015;9:ED15-7.

12. Jain D, Chopra P. Metastatic renal cell carcinoma of gall bladder. Saudi J Kidney Dis Transpl. 2013;24:100-4

13. Fang X, Gupta N, Shen SS, et al. Intraluminal polypoid metastasis of renal cell carcinoma in gallbladder mimicking gallbladder polyp. Arch Pathol Lab Med. 2010;134:1003-9.

14. Furukawa $H$, Mizuguchi $Y$, Kanai $Y$, Mukai K. Metastatic renal cell carcinoma to the gallbladder: color Doppler sonography and CT findings. AJR Am J Roentgenol. 1997;169:1466-7

15. Ishizawa T, Okuda J, Kawanishi T, Kitagawa T, Yakumaru K, Sekikawa T. Metastatic renal cell carcinoma of the gallbladder. Asian J Surg. 2006;29(3):145-8.

16. Win AZ. Renal cell carcinoma metastasis to the gallbladder detected by FDG-PET/CT. J Clin Med Res. 2014;6:482-6.

17. Bittinger $A$, Altekrüger I, Barth P. Clear cell carcinoma of the gallbladder. Pathol Res Pract. 1995;191:1259-65.

18. Botting AJ, Harrison EG Jr, Black BM. Metastatic patterns of renal carcinoma: an analysis of 687 necropsies. J Cancer Res Clin Oncol. 1988;114:605-12.

19. Terashima M, Abe H, Suga $\mathrm{K}$, et al. Two cases of renal cell carcinoma metastasized to the pancreas and to the gallbladder. Jpn J Gastroenterol Surg. 1990;23:1952-6.

20. Fullarton GM, Burgoyne M. Gallbladder and pancreatic metastases from bilateral renal carcinoma presenting with hematobilia and anemia. Urology. 1991:38:184-6
21. Golbey S, Gerard PS, Frank RG. Metastatic hypernephroma masquerading as acute cholecystitis. Clin Imaging. 1991;15:293-5.

22. Nagler J, McSherry CK, Miskovitz P. Asymptomatic metachronous metastatic renal cell adenocarcinoma to the gallbladder. Report of a case and guidelines for evaluation of intraluminal polypoid gallbladder masses. Dig Dis Sci. 1994;39:2476-9.

23. Pagano S, Ruggeri P, Franzoso F, Brusamolino R. Unusual renal cell carcinoma metastasis to the gallbladder. Urology. 1995;45:867-9.

24. King DH, Centeno AS, Saldivar VA, Sarosdy MF. Renal cell carcinoma metastatic to the gall bladder or prostate: two case reports. Urology. 1995 46:722-5.

25. Fujii Y. Renal cell carcinoma with gallbladder metastasis. Rinsho Hinyokika. 1995:49:405-7.

26. Coşkun F, Cetinkaya M, Cengiz O, Adsan O, Kulaçoğlu S, Eroğlu A. Metastatic carcinoma of the gallbladder due to renal cell carcinoma in the ectopic kidney. Acta Chir Belg. 1995;95:56-8.

27. Lombardo FP, Hertford DE, Shanahan EM, Kazam E. Color Doppler ultrasonographic evaluation of renal cell carcinoma metastasis to the gallbladder. J Ultrasound Med. 1996;15:725-8.

28. Kakimoto K. A case of renal cell carcinoma gallbladder metastasis. Rinsho Hinyokika. 1996;9:875-8.

29. Sparwasser C, Krupienski M, Radomsky J, Pust RA. Gallbladder metastasis of renal cell carcinoma. A case report and review of the literature. Urol Int. 1997:58:257-8.

30. Uchiyama T, Suzuki M, Fukuhara K, et al. A case of renal cell carcinoma gallbladder metastasis. Jpn J Gastroenterol. 1997:94:68-72.

31. Celebi I, Guzelsoy M, Yorukoglu K, Kirkali Z. Renal cell carcinoma with gallbladder metastasis. Int J Urol. 1998;5:288-90.

32. Ueki T. A case of renal cell carcinoma gallbladder metastasis. Shoukakigazou. 2001;3:373-9.

33. Gekiya M. A case of renal cell carcinoma gallbladder metastasis. Jpn J Urol Surg. 2002;15:67-9.

34. Aoki T, Inoue K, Tsuchida A, et al. Gallbladder metastasis of renal cell carcinoma: report of two cases. Surg Today. 2002;32:89-92.

35. Miyagi T, Kitagawa I, Katsumi T. Renal cell carcinoma with gallbladder metastasis. Rinsho Hinyokika. 2003;57:257-9.

36. Limani K, Matos C, Hut F, Gelin M, Closset J. Metastatic carcinoma of the gallbladder after a renal cell carcinoma. Acta Chir Belg. 2003;103:233-4.

37. Hellenthal NJ, Stewart GS, Cambio AJ, Delair SM. Renal cell carcinoma metastatic to gallbladder: a survival advantage to simultaneous nephrectomy and cholecystectomy. Int Urol Nephrol. 2007;39:377-9.

38. Nojima $\mathrm{H}_{\text {, }}$ Cho $\mathrm{A}$, Yamamoto $\mathrm{H}$, et al. Renal cell carcinoma with unusual metastasis to the gallbladder. J Hepatobiliary Pancreat Surg. 2008;15:209-12.

39. Sand M, Bechara FG, Kopp J, Krins N, Behringer D, Mann B. Gallbladder metastasis from renal cell carcinoma mimicking acute cholecystitis. Eur J Med Res. 2009;14:90-2.

\section{Submit your next manuscript to BioMed Central and we will help you at every step:}

- We accept pre-submission inquiries

- Our selector tool helps you to find the most relevant journal

- We provide round the clock customer support

- Convenient online submission

- Thorough peer review

- Inclusion in PubMed and all major indexing services

- Maximum visibility for your research

Submit your manuscript at www.biomedcentral.com/submit
Biomed Central 